\title{
(2) OPEN ACCESS \\ Use of simulation for education in hospital pharmaceutical technologies: a systematic review
}

\author{
Alexandra Garnier 다, 1,2 Romain Vanherp, ${ }^{1}$ Pascal Bonnabry 지 1,2 Lucie Bouchoud $^{1}$
}

'Department of Pharmacy, Geneva University Hospitals, Geneva, Switzerland ${ }^{2}$ Institute of Pharmaceutical Sciences of Western Switzerland, School of Pharmaceutical Sciences, University of Geneva, Geneva, Switzerland

\section{Correspondence to} Mrs Alexandra Garnier Pharmacy, Geneva University Hospitals, 1211 Geneve, Switzerland; alexandra. garnier@hcuge.ch

Received 23 September 2021 Accepted 30 November 2021

EAHP Statement 6: Education and Research.

\begin{abstract}
Objectives Because of the inherent risks facing

pharmacy technicians, and consequently also patients, initial and continuing education on hospital pharmaceutical technologies is essential. Simulation is a pedagogical tool now widely used in healthcare education. This study's objectives are to provide an overview of simulation's current place in the field of hospital pharmaceutical technology education, to classify these uses, and to discuss how simulation technologies could be better used in the future.
\end{abstract}

Data sources Two pharmacists independently searched PubMed, Embase, and Web of Science on 21 July 2020 and included studies in English or French that used simulation as an educational tool in the field of hospital pharmaceutical technologies, whether in academic teaching or professional practice.

Data summary Our search criteria resulted in 6248 articles, of which 24 were assessed for eligibility and 13 included in the qualitative synthesis. Simulation in hospital pharmaceutical technology education is used in three different ways: first, as a playful pedagogical tool, with error-based simulations (cleanrooms and preparation sheets with errors), or game-based simulations (escape games, role-plays, and board games); second, as an electronic tool with virtual reality (virtual cleanrooms and serious games), or augmented reality (3D glasses); finally, to evaluate chemical contamination (fluorescein and quinine tests) and microbiological contamination (media-fill tests) during compounding to periodically requalify pharmacy technicians.

Conclusion Further studies, including non-technical skills evaluations, are needed to confirm the usefulness of this innovative technique in training as efficiently as possible actual and future pharmacy professionals.

\section{INTRODUCTION}

Pharmaceutical technologies include methods, techniques, and instrumentation in the compounding of drugs and other preparations used in the diagnosis and treatment of patients. These drugs can be sterile or non-sterile. In the case of sterile drugs, the work environment is a cleanroom with a laminar flow hood or isolator, and aseptic techniques are required to maintain sterility throughout the process.

Healthcare simulation is a technique that creates a situation or environment to allow persons to experience a representation of a real healthcare event for the purpose of practise, learning, evaluation, testing, or to gain understanding of systems or human actions. ${ }^{1}$ In other words, simulation makes an experimental situation as close to reality as possible.
The efficacy of simulation methods depends on the trainer's perspective of the three axes of simulation fidelity ${ }^{2}$ : environmental fidelity, concerning the extent to which the simulator duplicates sensory information from the environment (a simulated cleanroom that looks like a real one); equipment fidelity, concerning the degree to which the simulator duplicates the appearance and feel of the real system (isolator or laminar flow hood identical to the one used daily); and psychological fidelity, concerning the degree to which the trainee perceives the simulation to be a believable surrogate for the real task. ${ }^{3}$

The French National Authority for Health lists three categories for simulation techniques in healthcare $^{4}$ : human simulation (standardised patients, role-playing), synthetic simulation (procedural simulators, patient simulators), and electronic simulation (3D environments, serious games, virtual reality, augmented reality). This classification is representative in medicine, and particularly in surgery or anaesthesia where simulation is regularly used, but is less appropriate for pharmaceutical courses and especially for hospital pharmaceutical technologies (HPT) where simulation is still in its infancy.

Several studies have shown the positive impact of using simulation in the training of pharmacy students and pharmacists to improve technical skills $^{5-7}$ (medicines reconciliation, medical emergencies, order verification) and non-technical skills $^{8-10}$ (communication, attitude, empathy). The above competencies mainly concern clinical pharmacists and their relationships with patients. It is hard to find simulation-based training dedicated to pharmacists working in pharmaceutical technologies, especially in hospital.

However, using simulation could enhance numerous pharmaceutical technology skills such as developing technical and functional expertise (training in routine or exceptional technical manipulations and implementing individual or team procedures such as hygiene or preparation of an isolator), building problem-solving and decisionmaking skills (in risk management-reproduction of adverse events, ability to cope with exceptional situations-of medication errors, broken vials, or extravasation and training in diagnostic and therapeutic clinical reasoning such as the analysis of prescriptions or preparation sheets), and promoting interpersonal, communication, and team-based skills (behaviour management of professional situations, teamwork, and communication using stress management or effective team communication). ${ }^{112}$ Considering these potentials, we decided to review the literature about the different uses of simulation 
in HPT. We believe that this literature review could help pharmacists in the conception and promotion of educational actions involving the use of simulation for HPT.

The present study's objectives were: (1) to provide an overview of simulation's current place in the field of HPT education; (2) to create a classification specific to HPT inspired by the HAS classification; and (3) to discuss how simulation in HPT could be better used in the future.

\section{MATERIAL AND METHODS Data sources}

This systematic review was performed according to the Preferred Reporting Items for Systematic reviews and Meta-Analyses (PRISMA) guidelines. ${ }^{13}$ The research strategy consisted of searching for relevant article titles and abstracts in the PubMed, Embase, and Web of Science databases. Keywords were chosen by consensus between the authors, with regards to our objectives. The words 'pharmaceutical technology' or 'pharmaceutical technologies' are rarely used in scientific articles which usually focus on a specific area of that field. That is the reason why the words 'cytotoxic OR chemotherapy OR aseptic OR parenteral nutrition' were selected for the pharmaceutical technologies axis. The word 'education' would have been too discriminating, therefore, it was not included among our keywords and only 'AND simulation' was used for the pedagogical method axis. An additional manual search was also conducted in the bibliographic reference lists of selected articles and in the journals and archives of specific congresses on pharmaceutical technologies.

\section{Inclusion and exclusion criteria}

Inclusion criteria were: design or use of simulation tools for education in pharmaceutical technologies, in initial education (university) or continuing education (hospital), published articles in English or French, and availability of the whole article. Exclusion criteria were: mathematical, computer, molecular, robotic, or cost simulation models.

\section{Analysis}

Two pharmacists (AG and RV), working independently, searched the literature on 21 July 2020 using the chosen keywords, and selected articles based on their titles. These articles were sorted using their abstracts, and duplicate entries were eliminated. An analysis file spreadsheet (Excel) was created to collect the relevant data from each article. After a reconciliation of the results (comparing Excel spreadsheets), any discrepant opinions about article selection were discussed with a third author $(\mathrm{PB})$ in order to reach a consensus. A final synthetic table was created from the detailed analysis file: author; title; year of publication; journal; country; study objectives; type of education-initial or continuing; field—chemotherapy or aseptic techniques; number and types of participants— pharmacists or pharmacy technicians; study length; evaluations of study limitations, impact, and Kirkpatrick evaluation levels (Reaction, Learning, Behaviour, Results) which are commonly used for evaluating training. ${ }^{14}$

\section{RESULTS}

The search strategy is presented in figure 1 and summaries of the included studies can be found in tables 1 and 2 .

Most of the simulation studies were carried out in France $(54 \% ; n=7)$, with the others occurring in Switzerland $(15 \%$; $\mathrm{n}=2)$ and the USA $(31 \% ; \mathrm{n}=4)$. Continuing education for professionals was represented $(77 \% ; n=10)$ more than initial education for students $(23 \% ; n=3)$. The training topics were

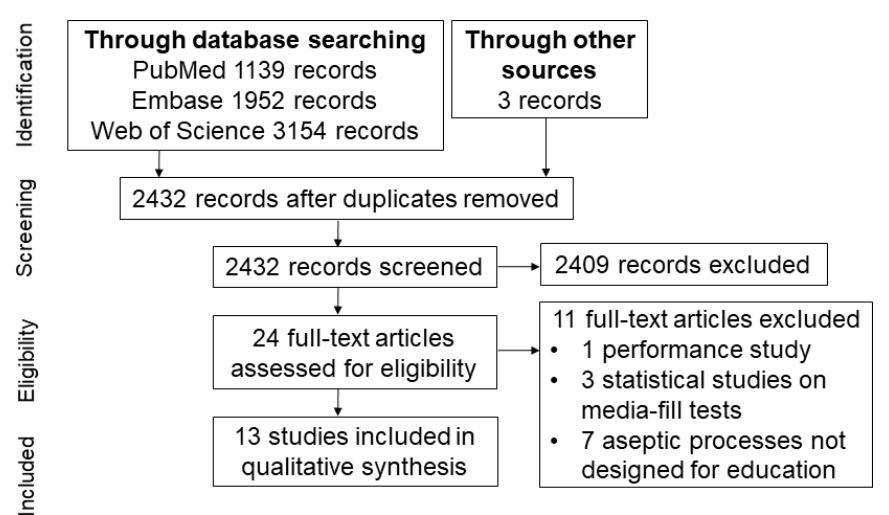

Figure 1 Flow diagram of the review article selection strategy of the literature.

competencies in the preparation of chemotherapies (31\%; $\mathrm{n}=4)$ or parenteral nutrition $(8 \% ; \mathrm{n}=1)$ and aseptic techniques for handling chemotherapies or other products $(61 \%$; $\mathrm{n}=8$ ). Simulation-based training (SBT) sessions were proposed in different settings, including real-life cleanrooms in daily use $(42 \% ; n=5)$, simulated cleanrooms $(42 \% ; n=5)$, and virtual cleanrooms $(16.7 \% ; n=2)$. Participation was mandatory $(8.3 \%$; $n=1)$, voluntary $(16.7 \% ; n=2)$, or not mentioned $(75 \% ; n=9)$.

When participants were pharmacists and pharmacy technicians $(62 \% ; n=8)$, the number of participants ranged from nine to 20 people. Sometimes participants were gathered from several hospitals $(15 \% ; n=2)$, thus increasing the number of participants from 45 to 72 people. When students were involved (23\%; $\mathrm{n}=3$ ), this number ranged from 109 to 150 .

\section{DISCUSSION}

To our knowledge, this is the first systematic literature review investigating the use of SBT in HPT. It highlights the limited number of published articles on this subject, since only 13 articles were reviewed, both in academic teaching and professional practice. Our research revealed that the use of SBT in HPT could be separated into three categories summarised in figure 2: the use of simulation as a playful tool, simulation using electronic tools, and simulation as a contamination verification tool.

\section{Simulation as a playful tool}

\section{The error-based simulation}

The chamber of errors, also called the cleanroom of errors, ${ }^{15} 16$ the isolator of errors, ${ }^{18}$ or the controlled atmosphere area of errors, ${ }^{19}{ }^{20}$ is an SBT approach where participants are asked to observe and report any of the several mistakes intentionally presented in a training room ${ }^{21} 22$ or on chemotherapy preparation sheets. ${ }^{23}{ }^{24}$ The global objective of these studies is to assess pharmacy technicians' knowledge of appropriate chemotherapy preparation practices. Some of these mistakes, which could lead to consequences for the patient (administering an expired medication or an overdose of vincristine, dispensing the wrong form of a drug), are major errors which participants are expected to spot. ${ }^{21}$

Integrating learning through errors into simulation approaches probably improves several competencies because trainees actively explore their environment and are explicitly encouraged to make and learn from mistakes, while competencies requiring improvement are pointed out. Error-based simulation is not only a game but also a cognitive model of safety improvement. 
Table 1 Summary of the articles about the use of simulations in hospital pharmaceutical technologies initial education

\begin{tabular}{|c|c|c|c|c|}
\hline Article information* & Article profile & Outcome & $\begin{array}{l}\text { Results before and after } \\
\text { simulation }\end{array}$ & Other key information \\
\hline \multirow{10}{*}{$\begin{array}{l}\text { Serag-Bolos et al }{ }^{27} \\
\text { Am J Pharm Educ (2018; USA) } \\
\text { Evaluating the impact of an oncology } \\
\text { simulation on students' knowledge } \\
\text { about oncology pharmacy practice } \\
\text { and evaluating how it affects } \\
\text { their perceptions of an oncology } \\
\text { pharmacist's role }\end{array}$} & \multirow{10}{*}{$\begin{array}{l}\text { Participants: } 109 \text { students } \\
\text { Participation: Mandatory (group of } \\
\text { 5-6) but voluntary pre- and post- } \\
\text { simulation assessments (alone) } \\
\text { Room: Training room } \\
\text { Equipment: Horizontal hood } \\
\text { Topic: As. Tech }\end{array}$} & Knowledge on ovarian cancer & Before: $86 \%$ & \multirow{6}{*}{$\begin{array}{l}\text { Students generally enjoyed the } \\
\text { oncology simulation and appreciated } \\
\text { the opportunity to practise key } \\
\text { concepts learnt in their curriculum } \\
\text { Kirkpatrick level: } 1,2\end{array}$} \\
\hline & & & After: $99 \%(p=0.0016)$ & \\
\hline & & Hypersensitivity reactions & $\begin{array}{l}\text { Before: } 72 \% \\
\text { After: } 92 \%(p=0.0002)\end{array}$ & \\
\hline & & Sidn fffoct & & \\
\hline & & slae efrects & After: $87 \%(p=0.11)$ & \\
\hline & & Jewellery in cleanroom & $\begin{array}{l}\text { Before: } 92 \% \\
\text { After: } 97 \%(p=0.17)\end{array}$ & \\
\hline & & Handwashing & $\begin{array}{l}\text { Before: } 57 \% \\
\text { After: } 92 \%(p<0.0001)\end{array}$ & \multirow{3}{*}{$\begin{array}{l}\text { Planning: } 40 \text { hours } \\
\text { Expert group: } 4 \text { pharmacy practice } \\
\text { faculty members (including a board- } \\
\text { certified oncology pharmacist) }\end{array}$} \\
\hline & & Aseptic preparation & $\begin{array}{l}\text { Before: } 50 \% \\
\text { After: } 61 \%(p=0.15)\end{array}$ & \\
\hline & & $\begin{array}{l}\text { Understanding the role of an } \\
\text { oncology pharmacist }\end{array}$ & $\begin{array}{l}\text { Before: } 3.8(0.9) \\
\text { After: } 4.5(0.8)(p<0.001)\end{array}$ & \\
\hline & & $\begin{array}{l}\text { Perception of the ability to prepare } \\
\text { orders }\end{array}$ & $\begin{array}{l}\text { Before: } 3.2(1.2) \\
\text { After: } 4.2(0.8)(p<0.001)\end{array}$ & $\begin{array}{l}\text { Budget: cost-saving strategies and } \\
\text { departmental funds }\end{array}$ \\
\hline $\begin{array}{l}\text { Patel et al }{ }^{31} \\
\text { Am J Pharm Educ (2011; USA) } \\
\text { Cultivating student confidence } \\
\text { in preparing IV medications and } \\
\text { emphasising safe medication } \\
\text { practices }\end{array}$ & $\begin{array}{l}\text { Participants: } 150 \text { students } \\
\text { Participation: NM } \\
\text { Room: Virtual } \\
\text { Equipment: NM } \\
\text { Topic: As. Tech }\end{array}$ & Written examination & $\begin{array}{l}\text { Before: } 89.6 \pm 7.3 \% \\
\text { After: } \\
\text { Year 1: } 91.2 \pm 7.5 \% \quad(p>0.05) \\
\text { Year 2: } 96.1 \pm 4.4 \%(p<0.001)\end{array}$ & $\begin{array}{l}\text { 88\%: Laboratory met their } \\
\text { expectations } \\
\text { Expert group: NM } \\
\text { Kirkpatrick level: } 1,2\end{array}$ \\
\hline \multirow{5}{*}{$\begin{array}{l}\text { Salman et al }{ }^{46} \\
\text { Pharmacy (2020; USA) } \\
\text { Demonstrating the value of } \\
\text { simulation-based activity in PN } \\
\text { education, as perceived by the } \\
\text { students }\end{array}$} & \multirow{5}{*}{$\begin{array}{l}\text { Participants: } 84 \text { students } \\
\text { Participation: Mandatory } \\
\text { Room: Classroom } \\
\text { Equipment: PN equipment } \\
\text { Topic: As. Tech }\end{array}$} & $\begin{array}{l}\text { Sterile compounding and aseptic } \\
\text { technique procedures involved in } \\
\text { the preparation of PN }\end{array}$ & $-5.48(p<0.0001)$ & \multirow[t]{5}{*}{$\begin{array}{l}\text { Comments were generally positive } \\
\text { Cost: US\$11.50 per student } \\
\text { Kirkpatrick level: } 1,2\end{array}$} \\
\hline & & $\begin{array}{l}\text { Process in which different } \\
\text { components are combined together }\end{array}$ & $-6.19(p<0.0001)$ & \\
\hline & & $\begin{array}{l}\text { Role of the pharmacy personnel in } \\
\text { the preparation of PN }\end{array}$ & $-5.29(p<0.0001)$ & \\
\hline & & $\begin{array}{l}\text { Comfortable performing the } \\
\text { calculations of the individual } \\
\text { components of PN }\end{array}$ & $-5.36(p<0.0001)$ & \\
\hline & & $\begin{array}{l}\text { An elective in PN would be a } \\
\text { beneficial course to have in the } \\
\text { College of Pharmacy curriculum }\end{array}$ & $-3.43(p<0.0001)$ & \\
\hline
\end{tabular}

*Article information: author, journal, year, country, type of education (continuing education or initial education), study's objective

As. Tech, aseptic technique; IV, intravenous; NA, not applicable; NE, not evaluated; NM, not mentioned; NS, non-significant; PN, parenteral nutrition.

\section{The game-based simulation}

Using games-structured tasks forcing participants to interact according to a set of rules-captures the essence of real-life situations. Very few published, innovative, game-based simulations exist in the field of pharmaceutical technologies. One good example is the escape room for learning good manufacturing practices. ${ }^{25}$ In addition to testing learners' theoretical and practical knowledge, the game aims to provide an instrument with which to study the processes involved in the actors' interactions. However, the success of these studies differs according to the participants' degree of involvement (better when they are deeply involved), the type of role being played (better when they play their own roles), and the response specificity (better when they feel free to behave as they want). ${ }^{26}$ In the HPT field, this role-playing method has been used to help students understand the role of an oncology pharmacist. ${ }^{27}$ Despite the discrepancy between role-playing and reality, students were able to apply (or identify gaps in) their knowledge and reinforce their critical thinking skills. Finally, several board-game-based simulations have been created to allow pharmacy technicians to check all the knowledge needed for the preparation of chemotherapies, such as a Trivial Pursuit-type game, a 37-card game, or a snakes-andladders board game. ${ }^{28-30}$ All of them have been well received thanks to their engaging visual, interactive, playful, and collaborative aspects.

\section{Simulation using electronic tools Virtual reality}

In 2011 the first virtual cleanroom was created to cultivate students' confidence in preparing intravenous medications appropriately while emphasising safe medication practices. ${ }^{31}$ At that time, it was challenging to find a suitable facility to host the sessions, access knowledgeable individuals capable of validating the virtual environment, and work within the limits of technology. Then a cleanroom simulator called LabQuest was developed to show that professionals trained using this system performed better than those trained using the traditional methods of video, quizzes, and PowerPoint presentations. ${ }^{32}$ This study is particularly interesting because it compared two homogeneous populations undergoing two different types of training.

As a mix between virtual reality and error-based simulation, the Association for the Digital and the Information for Pharmacy $(\mathrm{ADIPH})$ created a serious game including 60 errors in its SimUPAC $360^{\circ}$ virtual cleanroom. ${ }^{33}$

\section{Augmented reality}

Augmented reality's use in the field of educating employees about pharmacy technologies is still in its infancy, but results are encouraging. For the preparation of injectable drugs, 3D glasses can be used to reduce the number of medication errors related to a lack of information, by giving the step-by-step instructions 
Table 2 Summary of the articles about the use of simulations in hospital pharmaceutical technologies continuing education

\begin{tabular}{|c|c|c|c|}
\hline Article information* & Article profile & Outcome & $\begin{array}{l}\text { Results before and after } \\
\text { simulation }\end{array}$ \\
\hline $\begin{array}{l}\text { Loboda et al }{ }^{21} \\
\text { J Oncol Pharm Pract (2017; France) }\end{array}$ & $\begin{array}{l}\text { Participants: 15PA } \\
\text { Participation: NM }\end{array}$ & $\begin{array}{l}\text { Average score in finding errors } \\
\text { (score/20) }\end{array}$ & $\begin{array}{l}\text { Before: NA } \\
\text { After: } 59 \%(35-80 \%)\end{array}$ \\
\hline $\begin{array}{l}\text { Assessing pharmaceutical } \\
\text { assistants' (PA) knowledge level } \\
\text { in chemotherapy preparation } \\
\text { according to their capacity to detect } \\
\text { errors in preparation simulations }\end{array}$ & $\begin{array}{l}\text { Simulated training room } \\
\text { Equipment: Laminar flow hood } \\
\text { Topic: Chemo }\end{array}$ & $\begin{array}{l}\text { Detection rate of major errors } \\
\text { (ME) }\end{array}$ & $\begin{array}{l}\text { Before: NA } \\
\text { After: Satisfactory for } 2 \text { out of } 3 \\
\text { major errors }\end{array}$ \\
\hline $\begin{array}{l}\text { Cotteret et } \mathrm{al}^{22} \\
\text { J Oncol Pharm Pract (2019; France) }\end{array}$ & $\begin{array}{l}\text { Participants: } 20 \text { pharmacists and } \\
\text { pharmacy technicians (PT) }\end{array}$ & Rate of correct answers (score/14) & $\begin{array}{l}\text { Before: NA } \\
\text { After: } 58 \%(39-77 \%)\end{array}$ \\
\hline $\begin{array}{l}\text { Investigating pharmacy staff's } \\
\text { backgrounds and knowledge by } \\
\text { replicating a cytotoxic preparation } \\
\text { unit and } 14 \text { situations involving }\end{array}$ & $\begin{array}{l}\text { Participation: Voluntary } \\
\text { Simulated training room } \\
\text { Equipment: Isolator } \\
\text { Topic: Chemo }\end{array}$ & $\begin{array}{l}\text { Which professional identifies } \\
\text { which type of error? }\end{array}$ & $\begin{array}{l}\text { Errors in dispensing steps: more } \\
\text { were identified by pharmacists } \\
\text { Errors in chemical contamination: } \\
\text { more were identified by PT }\end{array}$ \\
\hline
\end{tabular}

errors

Sarfati et al ${ }^{23}$
J Clin Pharm Ther (2014; France)
Assessing the effectiveness of
a simulation-based learning
programme for preventing errors
in the preparation of injectable
antineoplastic agents
Berthod et al ${ }^{25}$
J Oncol Pharm Pract (2019;
Switzerland)
Evaluating improvements in
knowledge about GMP and
assessing participants' increase in
certainty (personal confidence) and
their appreciation of the programme

Denami $^{32}$

Pharm Technol Hosp Pharm (2016;

France)

Design and develop a cleanroom

simulator, LabQuest (LQ), and show

that professionals trained with LQ

perform better than those trained

using traditional methods (videos,

QCM, PPT)

\section{Harrison et $\mathrm{al}^{35}$}

Am J Health Syst Pharm (1996; USA)

Provide direct observation

and feedback to assess proper

techniques for handling cytotoxic

agents using a fluorescein test

$(0.5 \mathrm{mg} / \mathrm{mL})$

Favier et al ${ }^{36}$
J Pharm Clin (2003; France)
Prove the benefits of using a
fluorescein test to evaluate how
procedures are followed and
raise awareness about causes of
environmental contamination by
cytotoxic drugs

Participants: 12 pharmacy

professionals

Participation: NM

Real-life room in daily use

Equipment: NM

Topic: Chemo

\section{Participants: 72 professionals}

Participation: Voluntary

Training room

Equipment: Vertical hood

Topic: Chemo

Degree of certainty (personal

confidence)

\section{Detection of errors (score/25)}

First simulation: $52 \%$

Second simulation: $80 \%(p=0.04)$

1 year later: $84 \%$

1 year +3 months later: $80 \%^{24}$

\section{Correct answers}

Weighted score

Accomplishing gestures and

procedures

Detection of relevant errors

Virtual room

Equipment: Aseptic filling

machine

Topic: As. Tech

Traditional: $57.5 \%$

LabQuest: $89.3 \%$
Other key information

Positive staff feedback

Negative comments: discrepancy

between role-playing and

reality +lack of feedback

Study time: 1 year

Simulation time: $20 \mathrm{~min}$

Kirkpatrick level: 1

Satisfaction level: $8.7 \pm 1.0$ out

of 10

All respondents were satisfied/

very satisfied: workshop

considered relevant and

improving expertise

Study time: 1 month

Kirkpatrick level: 1

Expert group: 2 senior hospital

pharmacists and a pharmacy

student

Study time: 5 months

Expert group: 5 senior hospital

pharmacists, experts in oncology

Impact: awareness of risks during

the preparation of injectable

cancer drugs

Kirkpatrick level: 2

81\%: experience would improve

daily practice

$17 \%$ : not relevant for daily work

$27 \%$ : a few questions were

ambiguous

Study design and setting: many

weeks

Expert group: 4 senior

pharmacists, 1 PT Kirkpatrick level: 1,2

\section{Expert group: NM}

Kirkpatrick level: 2

\begin{tabular}{|c|c|}
\hline $\begin{array}{l}\text { Before: } 61 \pm 11 \% \\
\text { After } 3 \text { months: } 84 \pm 14 \% \\
(p=0.006)\end{array}$ & $\begin{array}{l}\text { Expert group: NM } \\
\text { Timing: } 26 \text { hours to conduct the } \\
\text { study }\end{array}$ \\
\hline $\begin{array}{l}\text { Before: } 92 \% \\
\text { After: } 23 \%(p<0.008)\end{array}$ & Kirkpatrick level: 2 \\
\hline $\begin{array}{l}\text { Before: } 89 \pm 8.6 \% \\
\text { After: } 85 \pm 5.9 \% \text { (NS) }\end{array}$ & \\
\hline $\begin{array}{l}\text { Before: } 75 \% \text { (E1) } \\
\text { After: } 88 \% \text { (E4) }\end{array}$ & $\begin{array}{l}\text { Expert group: NM } \\
\text { Timing: significant investment in } \\
\text { time for the pharmacist } \\
\text { Kirkpatrick level: } 2\end{array}$ \\
\hline
\end{tabular}

Continued
Participants: 13 professionals Real-life room in daily use Equipment: Vertical hood Topic: As. Tech

Participants: 9 professionals

Real-life room in daily use

Equipment: Hood

Topic: As. Tech

\section{Average score}

Positive contamination

Written test scores

Average score 
Table 2 Continued

\begin{tabular}{|c|c|c|c|c|}
\hline Article information* & Article profile & Outcome & $\begin{array}{l}\text { Results before and after } \\
\text { simulation }\end{array}$ & Other key information \\
\hline $\begin{array}{l}\text { Sadeghipour et al }{ }^{40} \\
\text { J Oncol Pharm Pract (2012; } \\
\text { Switzerland) } \\
\text { Using quinine as a tracer to evaluate } \\
\text { contamination levels by simulating } \\
\text { the preparation of injectable } \\
\text { cytotoxic drugs and designing } \\
\text { a procedure to check pharmacy } \\
\text { technicians' ability to work in a } \\
\text { clean manner }\end{array}$ & $\begin{array}{l}\text { Participants: } 29 \text { professionals } \\
\text { Participation: NM } \\
\text { Real-life room in daily use } \\
\text { Equipment: Isolator } \\
\text { Topic: As. Tech }\end{array}$ & $\begin{array}{l}\text { Mean accumulated quantities of } \\
\text { contamination }\end{array}$ & $\begin{array}{l}\text { Before: NA } \\
\text { After: } 6.2 \mu \mathrm{L}(0.6-23.8) \text { and }>10 \\
\text { spots (any pharmacy technician } \\
\text { with a contamination level } \\
\text { superior to mean level was a } \\
\text { candidate for a new training } \\
\text { programme) }\end{array}$ & $\begin{array}{l}\text { Expert group: NM } \\
\text { Timing: NM } \\
\text { Kirkpatrick level: none }\end{array}$ \\
\hline $\begin{array}{l}\text { Sigward et al }{ }^{42} \\
\text { Am J Health Syst Pharm (2012; } \\
\text { France) } \\
\text { Improving media-fill tests results by } \\
\text { introducing bacterial contamination } \\
\text { to the upper surfaces of vial } \\
\text { stoppers for the validation of } \\
\text { pharmacy technicians }\end{array}$ & $\begin{array}{l}\text { Participants: } 10 \text { professionals } \\
\text { Participation: NM } \\
\text { Training room } \\
\text { Equipment: Workbench } \\
\text { Topic: As. Tech }\end{array}$ & $\begin{array}{l}\text { Contamination rate of } 300 \\
\text { preparations }\end{array}$ & $\begin{array}{l}\text { Before: NA } \\
\text { After: } 2.3 \%\end{array}$ & $\begin{array}{l}\text { Expert group: NM } \\
\text { Timing: NM } \\
\text { Kirkpatrick level: none }\end{array}$ \\
\hline $\begin{array}{l}\text { Savry et al }{ }^{43} \\
\text { Am J Health Syst Pharm (2014; } \\
\text { France) } \\
\text { Validate manufacturing processes } \\
\text { and pharmacy technicians' } \\
\text { performances using MFT methods } \\
\text { and develop an isolator blackout }\end{array}$ & $\begin{array}{l}\text { Participants: } 12 \text { professionals } \\
\text { Participation: NM } \\
\text { Room: Real-life room in daily } \\
\text { use } \\
\text { Equipment: Isolator } \\
\text { Topic: As. Tech }\end{array}$ & $\begin{array}{l}\text { Validation of production } \\
\text { equipment } \\
\text { Validation of isolator blackout } \\
\text { procedure } \\
\text { Validation of manufacturing } \\
\text { processes }\end{array}$ & $\begin{array}{l}\text { Before: NA } \\
\text { After: NM } \\
\text { Before: NA } \\
\text { After: NM } \\
\text { Before: NA } \\
\text { After: NM }\end{array}$ & $\begin{array}{l}\text { Expert group: NM } \\
\text { Timing: NM } \\
\text { Kirkpatrick level: none }\end{array}$ \\
\hline
\end{tabular}

emergency procedure

*Article information: author, journal, year, country, type of education (continuing education or initial education), study's objective

As. Tech, aseptic technique; Chemo, chemotherapy; GMP, good manufacturing practices; MFT, media-fill test; NA, not applicable; NE, not evaluated; NM, not mentioned; NS, nonsignificant; PPT, PowerPoint; QCM, multiple choice question.

to the pharmacy technician in an ergonomic and practical way. ${ }^{34}$ Test feedbacks are positive, but efficiency results are unavailable for the moment.

\section{Simulation as a contamination verification tool}

Chemical contamination

The fluorescein test is a chemical contamination simulation process with two big advantages: it is safe, and contamination is easily visible under ultraviolet (UV) light. This method enables an assessment of the actions leading to contamination, as well as the frequency, location, and volumes of those contaminations. All these parameters are essential to knowing and controlling the exposure faced by pharmacy technicians, and this method, developed 25 years ago, ${ }^{3536}$ is still used for validating them. ${ }^{37-39}$ Other studies replace fluorescein with quinine. Quinine solution is non-toxic and fluorescent under UV light, but it is also colourless, preventing pharmacy technicians from seeing contamination directly and modifying their actions during production. One of the studies reviewed showed no correlation between contamination rates and pharmacy technicians' experience, but provided specific, individualised training when contamination quantities were over $10 \mu \mathrm{L} .{ }^{40}$ Others used the same method to insist on collective awareness of contamination risks and to work on improving manipulation gestures. ${ }^{41}$



Figure 2 Ways of using simulation for education in hospital pharmaceutical technologies. 
These educational approaches are interesting because pharmacy technicians can visualise and account for chemical contamination in real-time. It seems more appropriate to use quinine in such evaluations because its solution resembles the drugs handled regularly in hospital pharmacies, being mostly colourless. These tests thus appear essential for validating new pharmacy technicians and requalifying them periodically in order to detect any problems during manipulation.

\section{Microbiological contamination}

The media-fill test (MFT), sometimes known as 'process simulation', validates the pharmacy technician's ability to maintain sterility throughout the manufacturing process. Microbiological growth medium is used in place of the drug solution to test whether aseptic procedures are adequate to prevent contamination during real-life drug production. As there is a significant microbiological risk during the preparation of parenteral nutrients or chemotherapies, the MFT is a very good means of evaluating pharmacy technicians. The result necessary for the validation of an MFT is zero microbiological growth. It was found that cases of microbiological growth were always linked to Enterococccus faecalis and directly correlated to poor aseptic technique, ${ }^{42}$ and that contamination during aseptic compounding was linked to human errors rather than environmental contamination. ${ }^{43}$ The MFT is used to validate how pharmacy technicians manipulate their equipment and is thus considered a pedagogical tool. If a pharmacy technician's manipulations lead to microbiological growth, then they must be retrained in that particular manipulation gesture.

\section{Perspectives for improvement}

\section{Evaluation and educational content}

Strengthening and improving the use of simulation in educating pharmacy technicians about HPT requires permanent evaluation and adjustment of the methods used. Only five of the 12 articles considered reported collecting information on trainee satisfaction (Kirkpatrick's level 1). This ranged from a group discussion during a meeting ${ }^{21}$ to an individual survey composed of three questions using Likert scale responses. ${ }^{31}$ Such heterogeneity and subjectivity could be reduced by evaluating the relevance of the training content and the trainee's involvement as the training progresses, as suggested in the New World Kirkpatrick Model. ${ }^{44}$ Although level 2 evaluation was more common, with seven out of 12 articles reporting a pre/post-assessment of knowledge, we believe that it is still not enough to justify scientifically the use of simulation over other training methods. Level 3 evaluation measures the impact of training on daily practice and is considered the most difficult part of training to evaluate. Indeed, none of the studies included in this review reported it.

Finally, level 4 aims to evaluate the impact of the training on patients, which none of our reviewed studies managed, or on the institution. LabQuest claims a training cost saving of at least $€ 1500$ per new employee ${ }^{45}$ but, in this review, only two studies mentioned its costs in terms of material, time, and human resources. ${ }^{3146}$ If a positive return on investment represents the holy grail of SBT, the lack of studies including this aspect does not work in this educational approach's favour. Some authors have proposed a framework for calculating the return on investment in the field of healthcare, and this might be adaptable to the field of HPT. ${ }^{47}$ However, it is more likely that the future evaluation of SBT is based on the return on expectations, a collaborative process where the sponsor's expectations are identified and transformed into criteria of success, which are themselves transformed into assessment criteria.

\section{Monitoring non-technical skills}

A competency is the sum of knowledge, skill, and attitude. A study assessing 11 non-technical skills in a group of 15 pharmacy technicians showed a low score in leadership, commitment and work quality, which are all related to teamworking attitude. ${ }^{48}$ However, the importance of teamwork, communication, and collegiality-as non-technical skills_-was neither assessed nor discussed in any of the studies reviewed. There is a need, in the future, to develop this field.

\section{CONCLUSION}

This study reviews all the simulation-based training used for education in hospital pharmaceutical technologies, both in academic teaching and professional practice. The classification proposed in this paper-playful tool, electronic tool, and verification tool-provides a state of the art but will certainly evolve in parallel with the evolution of evaluation methods and the recognition of non-technical skills as a fully-fledged subject of learning. Further studies are needed to confirm the usefulness of this innovative technique in training as efficiently as possible actual and future pharmacy professionals.

\section{Twitter Pascal Bonnabry @bonnabry}

Contributors AG: research idea development, data acquisition, data analysis, results interpretation, drafting/revision of the paper. RV: data acquisition, data analysis, results interpretation. PB: research idea development, drafting/revision of the paper. LB: research idea development, drafting/revision of the paper.

Funding The authors have not declared a specific grant for this research from any funding agency in the public, commercial or not-for-profit sectors.

\section{Competing interests None declared.}

Patient consent for publication Not applicable.

Ethics approval This study does not involve human participants.

Provenance and peer review Not commissioned; externally peer reviewed.

Data availability statement Data are available upon reasonable request. Not applicable.

Open access This is an open access article distributed in accordance with the Creative Commons Attribution Non Commercial (CC BY-NC 4.0) license, which permits others to distribute, remix, adapt, build upon this work non-commercially, and license their derivative works on different terms, provided the original work is properly cited, an indication of whether changes were made, and the use is noncommercial. See: http://creativecommons.org/licenses/by-nc/4.0/.

\section{ORCID iDs}

Alexandra Garnier http://orcid.org/0000-0002-2397-0072

Pascal Bonnabry http://orcid.org/0000-0002-8690-649X

\section{REFERENCES}

1 Lopreiato J, Downing D, et al, the Terminology and Concepts Working Group. Healthcare simulation dictionary. 2 edn. Rockville, MD: Agency for Healthcare Research and Quality, 2020

2 Rehmann AJ, Mitman RD, Reynolds MC. A handbook of flight simulation fidelity requirements for human factors research. Technical report No. DOT/FAA/ CT-TN95/46. Wright-Patterson AFB, OH: Crew Systems Ergonomics Information Analysis Center, 1995.

3 Beaubien JM, Baker DP. The use of simulation for training teamwork skills in health care: how low can you go? Qual Saf Health Care 2004;13 Suppl 1:i51-6.

4 HAS. Guide de bonnes pratiques en matière de simulation en santé, 2012. Available: https://www.has-sante.fr/upload/docs/application/pdf/2013-01/guide_bonnes_ pratiques simulation sante guide.pdf

5 Katoue $M G$, Ker J. Simulation for continuing pharmacy education: development and implementation of a simulation-based workshop on medicines reconciliation for pharmacists. J Contin Educ Health Prof 2019;39:185-93.

6 Morris A, Young G, Roller L, et al. High-fidelity simulation increases pharmacy resident perceived competence during medical emergencies. Curr Pharm Teach Learn 2019;11:1016-21. 
7 Duffy AP, Henshaw A, Trovato JA. Use of active learning and simulation to teach pharmacy students order verification and patient education best practices with oral oncolytic therapies. J Oncol Pharm Pract 2021;27:834-41.

8 Kostoff M, Burkhardt C, Winter A, et al. An interprofessional simulation using the SBAR communication tool. Am J Pharm Educ 2016;80:157.

9 Clarke C, Sedlacek RK, Watson SB. Impact of a simulation exercise on pharmacy student attitude toward poverty. Am J Pharm Educ 2016;80:21.

10 Skoy ET, Eukel HN, Frenzel JE, et al. Use of an auditory hallucination simulation to increase student pharmacist empathy for patients with mental illness. Am J Pharm Educ 2016:80:142.

11 Lateef F. Simulation-based learning: just like the real thing. J Emerg Trauma Shock 2010;3:348-52.

12 Collomp R, Wong F, Duquesne J. Simulation in pharmaceutical compounding: generality and interest for operator's preparation. In: GERPAC Congress, Hyères, France, 1-3 October 2014. Oral Communication. Available: http://www.gerpac.eu/ la-simulation-en-pharmacotechnie-concept-general-et-interet-dans-la-formation-desoperateurs [Accessed 21 Jul 2020].

13 Moher D, Liberati A, Tetzlaff J, et al. Preferred reporting items for systematic reviews and meta-analyses: the PRISMA statement. Ann Intern Med 2009;151:264.

14 Kirkpatrick D. Evaluating training programs: the four levels. San Francisco: BerrettKoehler, 1994.

15 Martin J, Ribes O, Sainfort A. A playful approach to improve safety of the preparation process in a centralised pharmaceutical unit for chemotherapy drugs. Eur J Hosp Pharm 2017;24:A254-6.

16 Jaffuel M, Mangavelle J, Vernardet $\mathrm{S}$. The error room: a fun training tool for the pharmaceutical chemotherapy unit. Eur J Hosp Pharm 2019;26:A225.

17 Moine M, Nicoulaud JC, Roux C. An isolator of errors: a useful training tool for hospital technicians. in: GERPAC Congress, Hyères, France, 5-7 October 2016. oral communication. Available: http://www.gerpac.eu/isolateur-des-erreurs-un-outiloriginal-de-formation-continue-des-preparateurs [Accessed 21 Jul 2020].

18 Decarout L, Gailland T, Viard-Gaudin G. Set up of a mistakes isolator in the cytotoxic drug reconstitution unit (CDR). GERPAC Congress, 2018. Available: http://www. gerpac.eu/mise-en-place-d-un-isolateur-des-erreurs-en-unite-de-reconstitutioncentralisee-des-cytotoxiques-urcc [Accessed 21 Jul 2020].

19 Klaczynski V, Beausir A, Fournier C. How and why did we set up a controlled atmosphere area of errors? in: GERPAC Congress, Hyères, France, 7-9 October 2015. oral communication. Available: http://www.gerpac.eu/how-and-why-did-we-set-up-acontrolled-atmosphere-area-of-errors [Accessed 21 Jul 2020].

20 Bellegarde J. Controlled atmosphere area of errors: to learn otherwise. poster. GERPAC Congress, 2017. Available: http://www.gerpac.eu/controlled-atmospherearea-of-errors-to-learn-otherwise [Accessed 21 Jul 2020].

21 Loboda C, Vigneron J, Mulot C, et al. A "chamber of errors" adaptation to assess pharmaceutical assistants' knowledge in chemotherapy preparation. J Oncol Pharm Pract 2019;25:454-9.

22 Cotteret C, Marry S, Loeuillet R, et al. A virtual centralized cytotoxic preparation unit simulation to evaluate the pharmacy staff knowledge. J Oncol Pharm Pract 2019:25:1187-94.

23 Sarfati L, Ranchon F, Vantard N, et al. SIMMEON-Prep study: simulation of medication errors in oncology: prevention of antineoplastic preparation errors. $J$ Clin Pharm Ther 2015;40:55-62.

24 Sarfati L, Ranchon F, Vantard N. One-Year impact of a simulation-based-learning program on medication errors prevention during antineoplastic drugs preparation. conference commentary n ${ }^{\circ}$ PP22 in: ESCP-SFPC International workshop acquisition of pharmaceutical skills: simulation, serious games, innovative approaches, 22-23 June 2015, NICE, France. Int I Clin Pharm 2015;37.

25 Berthod F, Bouchoud L, Grossrieder F, et al. Learning good manufacturing practices in an escape room: validation of a new pedagogical tool. J Oncol Pharm Pract 2020:26:853-60.

26 Greenberg J, Eskew DE. The role of role playing in organizational research. J Manage 1993;19:221-41.

27 Serag-Bolos ES, Chudow M, Perkins J, et al. Enhancing student knowledge through a comprehensive oncology simulation. Am J Pharm Educ 2018;82:6245.
28 Danguy des Déserts L, Binson G, de Boisgrollier AC. Training in injectable antineoplastic preparation unit: let's play! Int J Clin Pharm 2015;37:959-69.

29 Danguy des Déserts L, Nowak C, Baudin I. Pharmacy technicians education: an innovative pedagogical tool. in: GERPAC Congress, Hyères, France, 2-4 October 2013 oral communication. Available: http://www.gerpac.eu/formation-des-preparateursmise-en-place-d-outils-pedagogiques-innovants [Accessed 21 Jul 2020].

30 Viallet A, Huynh-Lefeuvre L, Gauthier G. Formation des préparateurs en pharmacie : des connaissances contre des chim's! R-PCT-57. JFSPH Congress, 2019. Available: https://www.gsasa.ch/de/gsasa-kongresse/archiv-kongresse/20539/?oid=20347\& lang=de [Accessed 21 Jul 2020].

31 Patel S, Vincent AH, Abel SR, et al. A virtual clean room to teach USP 797 regulations for intravenous medications. Am J Pharm Educ 2011;75:7.

32 Denami M. Simulation: a powerful tool for training professional skills in Cleanrooms. Pharm Technol Hosp Pharm 2016;1.

33 Bonsergent M, Moine M, Sankhare D. Simulation by immersive virtual tour SimUPAC $360^{\circ}$ : a new tool for pharmacy tech in hospital school training. in: GERPAC Congress, Hyères, France, 3-5 October 2018. oral communication. Available: https://www. gerpac.eu/simulation-by-immersive-virtual-tour-simupac-360o-a-new-tool-forpharmacy-tech-in-hospital-school-training [Accessed 21 Jul 2020].

34 Ben Othman S. Augmented reality for risks management in injectable drugs preparation in hospital pharmacy. in: GERPAC Congress, Hyères, France, 1-3 October 2014. oral communication. Available: http://www.gerpac.eu/augmented-reality-forrisks-management-in-injectable-drugs-preparation-in-hospital-pharmacy [Accessed 21 Jul 2020].

35 Harrison BR, Godefroid RJ, Kavanaugh EA. Quality-assurance testing of staff pharmacists handling cytotoxic agents. Am J Health Syst Pharm 1996:53:402-7.

36 Favier B, Gilles L, Latour JF. Evaluation of pharmacy technicians handling cytotoxic agents in a centralized unit. J Pharm Clin 2003;22:107-12.

37 Desoil M, Fouéré A, Lester MA. Validation des manipulateurs : mise en place d'un test de remplissage aseptique couplé la fluorescéine dans une unité de reconstitution des cytotoxiques. In: SFPO Congress, Mandelieu, France, 13-14 October, 2011. Available: http://sfpo.com/squelettes/pdf/posters_2011/p29.pdf [Accessed 21 Jul 2020].

38 Acramel A, Acramel A, Dieye T, Gervais $R$, et al. Mise au point d'une méthode de formation et habilitation des manipulateurs de médicaments cytotoxiques. Le Pharmacien Hospitalier et Clinicien 2015:50:341.

39 Pagani M, Bertucat H, Rull-Espagnol F. Evaluation pratique du personnel d'une unité de reconstitution de cytotoxiques. In: Hopipharm Congress, Reims, France, 19-22 May, 2015. Available: https://www.synprefh.org/files/archives/hopi2015-poster-216.pdf [Accessed 21 Jul 2015].

40 Sadeghipour F, Lorenzini Kl, Ziewitz C, et al. Chemical contamination during the preparation of cytotoxics: validation protocol for operators in hospital pharmacies. J Oncol Pharm Pract 2013;19:57-64.

41 Taurin S, Kerjean G, Brouard A. Evaluation of chemical contamination when preparing chemotherapy treatments within a CCRU. oral communication. GERPAC Congress, 2011. Available: http://www.gerpac.eu/evaluation-de-la-contamination-chimique-lorsde-la-preparation-de-chimiotherapies-au-sein-d-une-urcc [Accessed 21 Jul 2020].

42 Sigward E, Fourgeaud M, Vazquez R, et al. Aseptic simulation test challenged with microorganisms for validation of pharmacy operators. Am J Health Syst Pharm 2012;69:1218-24.

43 Savry A, Correard F, Bennis Y, et al. Aseptic simulation test for cytotoxic drug production in isolators. Am J Health Syst Pharm 2014;71:476-81.

44 Kirkpatrick J. The new world Kirkpatrick model. Available: http://www. Kirkpatrickpartners.com/Our-Philosophy/The-New-World-Kirkpatrick-Model/ [Accessed 21 Jul 2020].

45 LabQuest. Available: http://www.labquest.fr/roi/ [Accessed 21 Jul 2020].

46 Salman G, Hua H, Nguyen M, et al. The role of a simulation-based activity on student perceptions of parenteral nutrition education. Pharmacy 2020;8. doi:10.3390/ pharmacy8030123. [Epub ahead of print: 21 Jul 2020].

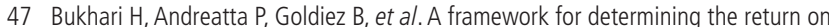
investment of simulation-based training in health care. Inquiry 2017;54:1-7.

48 Garnier A, Bonnabry P, Bouchoud L. Scoring of non-technical skills in a pharmaceutical technology unit. Posterposter R-PRP-37, 2020. Available: https://pharmacie.hug.ch/rd/ posters/ScoringNonTechnicalSkills_GSASA_2020.pdf 